\title{
Improvement of Yield and its Components, Grain Quality and Nutrients Uptake of Egyptian Hybrid Rice One by Application of Potassium Fertilizer and Cytokinin \\ Hashim, I. M.
}

Rice Res. Department, Field Crops Res. Inst., Agric. Res. Center (ARC), 33717 Sakha-Kafrelsheikh, Egypt

\begin{abstract}
One experiment was conducted in 2014 and respected in 2015 rice seasons at the farm of Rice Research \& Training Center, Sakha, Kafrelsheikh, Egypt. To study the impact of different time and method of potassium and various levels of Cytokinin and their interaction on the yield and its components, some grain quality characters and uptake of N, P and K. The treatments of potassium were (1) control ( Zero potassium) (K1), (2) Full dose as basal (B) (K2), (3) Half dose of potassium as basal $+2 \% \mathrm{~K}_{2} \mathrm{O}$ spray at mid-tillering and late booting (K3), (4) Half dose of potassium as basal $+2 \% \mathrm{~K}_{2} \mathrm{O}$ spray at mid tillering (K4), (5) Half dose of potassium as basal $+2 \% \mathrm{~K}_{2} \mathrm{O}$ spray at late booting (K5) and (6) $2 \% \mathrm{~K}_{2} \mathrm{O}$ spray at mid-tillering and late booting (K6). Cytokinin (Kinetin) treatments were Control (water spray) (C1), 5 ppm (C2), 10 ppm (C3), 15ppm (C4) each of them sprayed at both mid tillering and late booting. The design of the experiment was split plot with four replications. The main plots had the potassium treatments, while sub plots received the Cytokinin treatments. The studied characters were number of panicles $/ \mathrm{m}^{2}$, weight of panicle, number of grains/panicle, filled grain \%, 1000-grain weight, grain and straw yield, Some of grain quality characters and the uptake of nitrogen, phosphorus and potassium. The main results indicated that all the studied treatments of both potassium and Cytokinin caused an increase in all studied characters as compared with control. The best treatments of potassium was half of the dose of potassium $+2 \% \mathrm{~K} 2 \mathrm{O}$ sprayed at mid $+2 \% \mathrm{~K} 2 \mathrm{O}$ sprayed at L.B which caused a significant increase in all the previous studied characters because of its continuous supply the tested cultivar by $\mathrm{K}$ through the different stages. Also, sprayed Cytokinin at the rate of $15 \mathrm{ppm}$ at both mid tillering and late booting significantly increased all the studied characters because of the role of cytokinin for improving the growth of roots and shoots as well as the increasing in viability of rice leaves (late senescence of leaves). As for the interaction between potassium $(\mathrm{K})$ treatments and Cytokinin levels, the results revealed that the combination of half dose of potassium $+2 \% \mathrm{~K} 2 \mathrm{O}$ sprayed at both mid tillering and late booting with $15 \mathrm{ppm}$ sprayed at mid tillering and late booting produced the greatest values in all the studied characters.
\end{abstract}

Keywords: Oryza sativa, potassium sulphate, plant growth regulator, kinetin.

\section{INTRODUCTION}

Rice is one of the most important cereal crops of the world. Improving rice grain yield per unit land area is the only way to achieve increased rice production in area devoted to rice production. The productive potential of rice is mainly governed by soil types, fertilizer, water, genotypes and agronomic practices adopted in a particular climate. But, deficiency of plant growth regulators at any stage of plant may create a barrier to attain high grain yield. The Cytokinin regulates cell division and translocation of assimilates and there by affecting the yield potential of plants (Pandey et al., 2001). The application of a small amount of plant growth regulators affects physiological activities and helps to absorb applied nutrients leading increased yield and quality (Sakakibara et al., 2006)

Potassium is required by plants in approximately the same or slightly larger amount as nitrogen. Most of the functions of $\mathrm{K}$ in the plant are indirect, that $\mathrm{K}$ is necessary for other chemical reactions to operate properly. Approximately 60 enzymes require the presence of $\mathrm{K}$. Pavithira et al. 2017 reported that in addition to the normal function of potassium, optimum $\mathrm{K}$ nutrition increases the number of spikelets per panicle, percentage of filled grains, and 1000-grain weight in rice. It also gives strength to the rice plant and helps stand firm against strong winds by improving the rigidity of pseudo stems and stalks. This is important to reduce lodging. Overall, all these affect the quality of crop produce.

\section{MATERIALS AND METHODS}

A field experiment was carried out using transplanted rice system at the Experimental farm of the Rice Research \& Training Center (RRTC), Sakha, Kafr El - Sheikh, Egypt, during the two rice seasons of 2014 and
2015 to study the impact of Cytokinin levels and different methods and time of potassium application on the, yield and yield components as well as, some grain quality characters and nitrogen ,phosphorus and potassium uptake of Egyptian Hybrid Rice 1 cultivars".

Soil Analysis:

Soil sample was taken before cultivation, crushed then grind to pass through $2 \mathrm{~mm}$ sieve. Some physical and chemical analysis was determined according to Cottenie et $a l$, (1982). The results are presented in Table 1.

Experimental design was laid out in a split plot design with four replications. The main plots were devoted to the potassium treatments at the rate of $60 \mathrm{Kg}$ $\mathrm{K} 2 \mathrm{O} \mathrm{ha}{ }^{-1}$ as potassium sulphate form $\left(120 \mathrm{Kg} \mathrm{ha}^{-1}\right)$, while Cytokinin treatments were located in sub plots.

A. Potassium treatments:

1. Zero potassium $(\mathrm{K} 1)$.

2. Full dose as basal (B) (K2).

3. Half dose of potassium as basal $+2 \% \mathrm{~K}_{2} \mathrm{O}$ spray at mid-tillering (15 days after transplanting ) and late booting (95days after transplanting ) (K3).

4. Half dose of potassium as basal $+2 \% \mathrm{~K}_{2} \mathrm{O}$ spray at mid-tillering (K4).

5. Half dose of potassium as basal $+2 \% \mathrm{~K}_{2} \mathrm{O}$ spray at late booting (K5).

6. sprayed $2 \% \mathrm{~K}_{2} \mathrm{O}$ at mid-tillering and late booting (K6).

B. Cytokinin treatments:

1. Control (without Cytokinin) (C1)

$2.5 \mathrm{ppm}$

3. $10 \mathrm{ppm}$

4. $15 \mathrm{ppm}$

Both potassium and Cytokinin were applied according to the experimental treatments as previously mentioned. 
Table 1. Some physical and chemical analysis of the soil at the experimental sites during 2014 and 2015.

\begin{tabular}{|c|c|c|}
\hline Soil Properties & 2014 & 2015 \\
\hline Clay $\%$ & 57.0 & 54.5 \\
\hline Silt \% & 32.0 & 35.0 \\
\hline Sand \% & 11.0 & 11.5 \\
\hline Texture $\%$ & Clayey & Clayey \\
\hline Organic matter $\%$ & 1.65 & 1.55 \\
\hline Available $\mathrm{P}, \mathrm{mg} \mathrm{kg}^{-1}$ & 13.00 & 12.00 \\
\hline Available $\mathrm{NH}_{4}, \mathrm{mg} \mathrm{kg}^{-1}$ & 12.5 & 12.6 \\
\hline Available $\mathrm{NO}_{3}, \mathrm{mg} \mathrm{kg}^{-1}$ & 10.0 & 11.8 \\
\hline Available $\mathrm{K}, \mathrm{mg} \mathrm{kg}^{-1}$ & 321 & 336 \\
\hline $\mathrm{pH}(1: 2.5$ soil suspension $)$ & 8.45 & 8.2 \\
\hline EC dS m${ }^{-1}$ (soil past) & 3.0 & 2.05 \\
\hline \multicolumn{3}{|l|}{ Soluble cations, meq. $\mathrm{L}^{-1}$} \\
\hline $\mathrm{Ca}^{++}$ & 7.2 & 7.0 \\
\hline $\mathrm{Mg}^{++}$ & 1.6 & 1.5 \\
\hline $\mathrm{K}^{+}$ & 0.5 & 0.5 \\
\hline $\mathrm{Na}^{+}$ & 13.0 & 12.0 \\
\hline \multicolumn{3}{|l|}{ Soluble anions, meq. $\mathrm{L}^{-1}$} \\
\hline $\mathrm{CO}_{3}^{--}$ & 0.00 & 0.00 \\
\hline $\mathrm{HCO}_{3}^{--}$ & 5.3 & 5.0 \\
\hline $\mathrm{Cl}^{-}$ & 15.0 & 14.0 \\
\hline $\mathrm{SO}_{4}{ }^{--}$ & 2.0 & 2.0 \\
\hline
\end{tabular}

Nursery area of the experiment was identified, plowed twice then the well dry leveled was done. Phosphorus, potassium were applied after the second plowing and nitrogen was applied after dry leveling and immediately irrigated and zinc sulphate was applied as recommended. Seeds at the rate $24 \mathrm{~kg}$ seeds/ha was soaked in fresh water for $24 \mathrm{hr}$., then incubated for $48 \mathrm{hr}$ to hasten early germination. Pre-germinated seeds were uniformly broadcasted in the nursery. The date of sowing was on April 27 in 2014 and April 26 in 2015 rice seasons. After 30 days from sowing, the seedling was carefully pulled and transferred to permanent field and transplanted in each plot at the space of 20 X20 cm between hill and rows and the plot size was $15 \mathrm{~m}^{2}$. The permanent field was prepared as the same as nursery. Phosphorus fertilizer as form of single super phosphate at the rate of $36 \mathrm{~kg} \mathrm{P}_{2} \mathrm{O}_{5} /$ ha was applied during land preparation, while nitrogen fertilizer as form of urea at the rate of $165 \mathrm{~kg} \mathrm{~N} / \mathrm{ha}$ was applied as three equal dose as recommended. The weeds were chemically controlled in nursery and permanent field using Saturn $50 \%$ after 7 days from planting.

Studied characters:

Number of panicle $/ \mathrm{m}^{2}$, average weight of panicle, and percentage of filled grains were estimated immediately before harvesting. Grain and Straw yield were estimated as follow: central $10 \mathrm{~m}^{2}$ in each plot was identified and harvested, after three days the weight of both straw and grain together was recorded and then threshed. The separated grains were weighted and adjusted to $14 \%$ moisture content and transferred to ton/ha. Also, straw yield was weighted and computed to ton/ha.

Grain quality characters; hulling, milling and head rice were determined in grain quality lab. Dried samples were ground to powder and digested according to the method of Chapman and Pratt 1961. The uptake of nitrogen, phosphorus and potassium were determined in Agronomy lab. Nitrogen content was determined using Orange - $\mathrm{G}$ dye method according to Hafez and mikkelsen (1981). Phosphorus was determined calorimetrically by ascorbic acid according to Olesn and Deam (1965) and modified by Watanabe and Olsen (1965). Potassium was determined by the flame photo meter as described by Jackson (1967).

All obtained data were statistical analyzed according to the technique of analysis of variance (ANOVA) for the split plot design as published by Gomez and Gomez (1984). Treatments' means were compared using LSD test at $5 \%$ probability level as described by Snedecor and Cochran (1980).

\section{RESULTS AND DISCUSSION}

Number of panicles $/ \mathrm{m}^{2}$, panicle weight and number of grains/ panicle as affected by both potassium and Cytokinin treatments are presented in table (2).

Table 2. Number of panicles $\mathrm{m}^{-2}$, panicle weight and number of grains panicles ${ }^{-1}$ of Egyptian Hybrid Rice 1 as affected by potassium and Cytokinin treatments during 2014 - 2015 seasons.

\begin{tabular}{lcccccc}
\hline \multirow{2}{*}{ Treatments } & \multicolumn{3}{c}{ No. of panicles $\mathbf{~ m}^{-2}$} & \multicolumn{2}{c}{ Panicle weight } & \multicolumn{2}{c}{ No. of grains panicles $^{-1}$} \\
\cline { 2 - 7 } & $\mathbf{2 0 1 4}$ & $\mathbf{2 0 1 5}$ & $\mathbf{2 0 1 4}$ & $\mathbf{2 0 1 5}$ & $\mathbf{2 0 1 4}$ & $\mathbf{2 0 1 5}$ \\
\hline Potassium treatments: & 329.3 & 316.4 & 3.28 & 3.15 & 136.07 & 137.50 \\
$\left(\mathrm{~K}_{1}\right)$ Control & 519.5 & 511.7 & 4.08 & 3.86 & 151.49 & 154.05 \\
$\left(\mathrm{~K}_{2}\right)$ Basle all amount & 526.2 & 499.4 & 4.18 & 3.93 & 150.52 & 153.10 \\
$\left(\mathrm{~K}_{3}\right)$ 1/2 B +Spray Md.T+ L.B & 453.3 & 418.3 & 3.66 & 3.52 & 140.65 & 144.45 \\
$\left(\mathrm{~K}_{4}\right)$ 1/2 B + Spry at Md T & 460.3 & 422.7 & 3.71 & 3.74 & 138.67 & 140.35 \\
$\left(\mathrm{~K}_{5}\right)$ 1/2 B + Spray at L.B & 502.9 & 470.1 & 3.49 & 3.41 & 138.62 & 139.86 \\
$\left(\mathrm{~K}_{6}\right)$ Spray Md.T+ L.B & 15.4 & 15.4 & 0.15 & 0.17 & 10.70 & 11.40 \\
LSD 0.05 & & & & & & \\
Cytokinin ppm: & 432.1 & 400.3 & 3.30 & 3.15 & 135.10 & 137.23 \\
$\left(\mathrm{C}_{1}\right)$ Control (water spry) & 451.7 & 425.1 & 3.58 & 3.44 & 139.23 & 142.49 \\
$\left(\mathrm{C}_{2}\right)$ 5 ppm & 491.4 & 468.9 & 4.08 & 3.91 & 147.80 & 149.51 \\
$\left(\mathrm{C}_{3}\right)$ 10 ppm & 485.8 & 464.7 & 3.97 & 3.89 & 148.54 & 150.30 \\
$\left(\mathrm{C}_{4}\right)$ 15 ppm & 16.7 & 17.1 & 0.14 & 0.08 & 7.43 & 9.40 \\
LSD at 0.05 & $* *$ & $* *$ & $* *$ & $* *$ & $* *$ & $*$ \\
Interaction & & & & &
\end{tabular}


Data indicated that the application of all either potassium treatments or different levels of Cytokinin (CK) caused a significant increase in number of panicle $/ \mathrm{m} 2$ as compared with control treatments. As for potassium treatments, the highest number of panicles $/ \mathrm{m}^{2}$ was obtained when potassium $(\mathrm{K})$ was applied $1 / 2$ Basal $+2 \% \mathrm{~K}$ sprayed at mid-tillering and late booting (K3) followed by the application of all dose of potassium basally (K2) without any significant difference between them. The treatments (K6) came after the previous two treatments K2 and K3 but did not reach to significant. The other treatments came in between. The lowest number of panicles $/ \mathrm{m}^{2}$ was obtained from control treatment. These results were hold true in the two studied seasons. Findings of Pavithira et al. 2017 are also in agreement with the present results. The increases in number of panicles when potassium applied bassally before planting could be attributed to the role of potassium for enhancing the nodes to emerge more early tillers by the other meaning more effective tillers (more number of panicles). In addition, spraying rice by $2 \% \mathrm{~K} 2 \mathrm{O}$ at mid-tillering (Md.T) make continuous supply the plant by $\mathrm{K}$ during vegetative stage that increase the effective tillers and minimizing the unproductive tillers. It means that its more benficial and increase number of tillers. Findings of Pavithira et al. 2017 are also in agreement with the present results.

Data in Table 2 also showed that foliar spray of Cytokinin (CK) at mid-tillering and late booting period significantly increased number of panicles per $\mathrm{m}^{2}$ compared with control. While the highest number of panicles per $\mathrm{m}^{2}$ were recorded with 10 and $15 \mathrm{ppm}$ Cytokinin without any significant differences between them in both seasons of study. Significant variation in the interaction between potassium treatments and Cytokinin levels (CK) in number of panicles were observed in (Table 3). Among the treatments, the combination (K3C3) gave the highest value of number of panicles per $\mathrm{m}^{2}$ while the lowest value of number of panicle was found with the combination of $\mathrm{K}_{1}$ with $\mathrm{C}_{1}$.

Table 3. Number of panicles $\mathrm{m}^{-2}$ of Egyptian Hybrid Rice 1 as affected by the interaction between potassium treatment and Cytokinin concentration during 2014 - 2015 seasons.

\begin{tabular}{|c|c|c|c|c|c|c|c|c|}
\hline \multirow{3}{*}{ Potassium treatments } & \multicolumn{8}{|c|}{ Cytokinin ppm } \\
\hline & \multicolumn{4}{|c|}{2014} & \multicolumn{4}{|c|}{2015} \\
\hline & $\left(\mathrm{C}_{1}\right) \mathbf{0}$ & $\left(C_{1}\right) 5$ & $\left(C_{1}\right) 10$ & $\left(C_{1}\right) 15$ & $\left(C_{1}\right) 0$ & $\left(C_{1}\right) 5$ & $\left(C_{1}\right) 10$ & $\left(C_{1}\right) 15$ \\
\hline$\left(\mathrm{K}_{1}\right)$ Control & 311.7 & 329.0 & 338.7 & 337.7 & 299.7 & 310.0 & 326.0 & 330.0 \\
\hline$\left(\mathrm{K}_{2}\right)$ Basle all amount & 466.7 & 488.3 & 557.3 & 565.7 & 459.0 & 482.0 & 553.7 & 562.0 \\
\hline$\left(\mathrm{K}_{3}\right)^{1 / 2} \mathrm{~B}+$ Spray Md.T+ L.B & 473.7 & 491.3 & 571.3 & 568.7 & 432.3 & 461.0 & 553.3 & 551.0 \\
\hline$\left(\mathrm{K}_{4}\right)^{1 / 2} \mathrm{~B}+$ Spry at Md T & 432.7 & 456.7 & 462.0 & 461.7 & 390.3 & 422.7 & 429.0 & 431.0 \\
\hline$\left(\mathrm{K}_{5}\right)^{1 / 2} \mathrm{~B}+$ Spray at L.B & 442.3 & 472.0 & 475.3 & 451.7 & 400.0 & 435.7 & 438.3 & 416.7 \\
\hline$\left(\mathrm{K}_{6}\right)$ Spray Md.T+ L.B & 465.7 & 472.7 & 543.7 & 529.7 & 420.7 & 439.0 & 513.3 & 507.3 \\
\hline LSD at 0.05 & \multicolumn{4}{|c|}{24.8} & \multicolumn{4}{|c|}{25.6} \\
\hline
\end{tabular}

The increase in number of panicles due to Cytokinin application could be attributed mainly to the break of apicle dominant which led to promote the lateral growth of plant i.e effective tillers (number of panicle and leaves due to the increase in cell division and elongation beside the chlorophyll content which led increase the photosynthesis and its products and their partitioning through the plant organs, one of them is effective tillers (number of panicles). Also, the increase in number of tillers due to potassium application could be attributed mainly to increasing uptake of nutrients especially $\mathrm{N}$ and $\mathrm{P}$ which cause higher activation of nodes to emerge more number of early tillers that always are effective tiller (number of panicles). These results supported the work by Sakakibara et al., 2006 and Dwived et al. 2006.

Data in Table 2 present the effect of potassium and Cytokinin application on panicle weight in the two seasons. The application of potassium treatments significantly increased panicle weight as compared with control. The heaviest panicle was obtained when the tested cultivar fertilized with $\mathrm{K} 3$ and K2. The lightest panicles were obtained when no potassium was applied. The increase in panicle weight by potassium application might be due to more $\mathrm{K}$ utilization by the plant resulting in more chlorophyll synthesis that increase photosynthetic products and efficient translocation of assimilates from leaves especially flag leaf to spikelet with high filling rate resulted in heavier panicles. Ali et al. 2005 and Zain and Ismail 2016 found similar trend. Panicle weight was significantly high when Cytokinin was applied at 10 or $15 \mathrm{ppm}$. While the lowest values were recorded when Cytokinin was not applied. The increase in panicle weight by Cytokinin application might be due to the role of Cytokinin for increasing grain size due to the increase in cell division and cell elongation, Cytokinin also, increase the nutrients uptake, chlorophyll contents consequently photosynthesis and its products which translocated directly to spikelet of panicles with high filling rate and percentage resulted increases the weight of panicles. The result is in conformity with Jianchang Yang et al., 2000.

Data in Table 4 revealed that there was a significant difference in panicle weight due to the interaction between potassium and Cytokinin. The combination of $\mathrm{K}_{3}$ with $\mathrm{C} 3$ gave the heaviest panicle while the lightest panicle was obtained from the combination of $\mathrm{K}_{1}$ with $\mathrm{C}_{1}$.

Data of the interaction between potassium treatments and Cytokinin levels on number of grains panicle $^{-1}$ are presented in Table 2. Number of grains panicle $^{-1}$ were increased with the application of any the treatments of potassium as compared with control. Plant which treated by $\mathrm{K} 2$ or $\mathrm{K} 3$ produced the highest number of grains panicles ${ }^{-1}$. While the plants that did not receive any potassium gave the lowest values of number of grains panicles $^{-1}$. These results were hold true in both studied seasons. Number of grains panicles ${ }^{-1}$ was the greatest when Cytokinin was applied at the rate of 10 or $15 \mathrm{ppm}$. While the lowest values were recorded when Cytokinin was not applied. 
Data in Table 5 explained that, highly significant differences in the interaction between potassium and Cytokinin application in number of grains per panicles were found in both studied seasons. The maximum number of grains panicles ${ }^{-1}$ were obtained when the tested cultivar treated with both $\mathrm{K} 3$ and $\mathrm{K} 2$ in combined with both of $\mathrm{C} 4$ and $\mathrm{C} 3$ in both studied seasons. The increases in number of grains/panicle with the application of both potassium and Cytokinin could be attributed to the role of Cytokinin for increase the growth of different plant organs one of them is the panicle. Cytokinin cause an increase in the length, number of branches panicles as well as number of spikelet's and its size beside the increasing in the viability of flag leaf plus second and third leaves which representative about $75 \%$ from the total photosynthesis in hybrid rice. Moreover, because of the potassium is co-activator for about 64 enzymes in rice plant some of them are transferring enzymes. These group of enzymes translocated higher amount of photosynthesis products (assimilate to the spikelet's and filled the greatest number of spikelet's due to Cytokinin resulted in higher number of grains per panicle. These findings are in an agreement with those reported by Tanaka et al. (1995).

Table 4. Panicle weight of Egyptian Hybrid Rice 1 as affected by the interaction between potassium treatments and Cytokinin concentration during 2014 - 2015 seasons.

\begin{tabular}{|c|c|c|c|c|c|c|c|c|}
\hline \multirow{3}{*}{ Potassium treatments } & \multicolumn{8}{|c|}{ Cytokinin ppm } \\
\hline & \multicolumn{4}{|c|}{2014} & \multicolumn{4}{|c|}{2015} \\
\hline & $\left(C_{1}\right) 0$ & $\left(C_{1}\right) 5$ & $\left(C_{1}\right) 10$ & $\left(C_{1}\right) 15$ & $\left(C_{1}\right) 0$ & $\left(C_{1}\right) 5$ & $\left(C_{1}\right) 10$ & $\left(C_{1}\right) 15$ \\
\hline$\left(\mathrm{K}_{1}\right)$ Control & 2.85 & 3.11 & 3.59 & 3.58 & 2.91 & 3.07 & 3.37 & 3.23 \\
\hline$\left(\mathrm{K}_{2}\right)$ Basle all amount & 3.81 & 3.87 & 4.51 & 4.12 & 3.35 & 3.61 & 4.30 & 4.19 \\
\hline$\left(\mathrm{K}_{3}\right)_{1 / 2}^{1 / 2}+$ Spray Md.T+ L.B & 3.48 & 4.02 & 4.74 & 4.49 & 3.36 & 3.59 & 4.36 & 4.39 \\
\hline$\left(\mathrm{K}_{4}\right) 1 / 2 \mathrm{~B}+$ Spry at Md T & 3.29 & 3.44 & 3.99 & 3.90 & 3.06 & 3.21 & 3.85 & 3.96 \\
\hline$\left(\mathrm{K}_{5}\right) 1 / 2 \mathrm{~B}+$ Spray at L.B & 3.20 & 3.52 & 4.06 & 4.07 & 3.16 & 3.85 & 3.98 & 3.95 \\
\hline$\left(\mathrm{K}_{6}\right)$ Spray Md.T+ L.B & 3.18 & 3.50 & 3.61 & 3.68 & 3.06 & 3.31 & 3.62 & 3.63 \\
\hline LSD at 0.05 & \multicolumn{4}{|c|}{0.19} & \multicolumn{4}{|c|}{0.17} \\
\hline
\end{tabular}

Table 5. Number of grains panicles ${ }^{-1}$ of Egyptian Hybrid Rice 1 as affected by the interaction between potassium treatment and Cytokinin concentration during $2014-2015$ seasons.

\begin{tabular}{|c|c|c|c|c|c|c|c|c|}
\hline \multirow{3}{*}{ Potassium treatments } & \multicolumn{8}{|c|}{ Cytokinin ppm } \\
\hline & \multicolumn{4}{|c|}{2014} & \multicolumn{4}{|c|}{2015} \\
\hline & $\left(\mathrm{C}_{1}\right) \mathbf{0}$ & $\left(C_{1}\right) 5$ & $\left(C_{1}\right) \mathbf{1 0}$ & $\left(C_{1}\right) 15$ & $\left(\mathrm{C}_{1}\right) \mathbf{0}$ & $\left(C_{1}\right) 5$ & $\left(C_{1}\right) \mathbf{1 0}$ & $\left(C_{1}\right) 15$ \\
\hline$\left(\mathrm{K}_{1}\right)$ Control & 127.86 & 135.20 & 140.20 & 141.00 & 130.00 & 136.20 & 141.94 & 141.86 \\
\hline$\left(\mathrm{K}_{2}\right)$ Basle all amount & 145.74 & 148.80 & 155.60 & 155.80 & 147.66 & 151.54 & 158.60 & 158.40 \\
\hline$\left(\mathrm{K}_{3}\right)^{1 / 2} \mathrm{~B}+$ Spray Md.T+ L.B & 135.20 & 145.74 & 160.40 & 160.74 & 138.40 & 147.26 & 163.34 & 163.40 \\
\hline$\left(\mathrm{K}_{4}\right)^{1 / 2} \mathrm{~B}+$ Spry at Md T & 133.54 & 134.86 & 146.60 & 147.60 & 135.60 & 145.14 & 147.66 & 149.40 \\
\hline$\left(\mathrm{K}_{5}\right)^{1 / 2} \mathrm{~B}+$ Spray at L.B & 135.80 & 136.26 & 140.26 & 142.34 & 136.80 & 138.26 & 142.40 & 143.94 \\
\hline$\left(\mathrm{K}_{6}\right)$ Spray Md.T+ L.B & 132.46 & 134.54 & 143.74 & 143.74 & 134.94 & 136.54 & 143.14 & 144.80 \\
\hline LSD at 0.05 & \multicolumn{4}{|c|}{11.70} & \multicolumn{4}{|c|}{10.54} \\
\hline
\end{tabular}

Filled grains percentage as affected by potassium and Cytokinin application is presented in Table 6. Data indicated that filled grains percentage significantly increased with the application of all potassium treatments as compared with the control. The greatest value of filled grain \% was obtained from both $\mathrm{K} 2$ and $\mathrm{K} 3$ treatments. While the plants did not receive any potassium fertilizer gave the lowest values of filled grains percentage. These results were true in the both studied seasons. The increase in filled grain \% due to the application of $\mathrm{K}$ could be attributed to that potassium is closely related to the starch biosynthesis. Since ADP glucose starch synthesis, which is the primary enzyme for starch synthesis, increase it's activity due to the presence of potassium, it's assumed that potassium acts an important physiological function in the quick progress of starch synthesis. These findings are in an agreement with those reported by Tanaka et al 1995 .

Filled grains percentage was significantly high when Cytokinin was applied at the rate of either 10 or 15 ppm. While the lowest value were recorded when Cytokinin was not applied. This could be attributed to the role Cytokinin for increase the viability of leaves as a result to assimilation of protein and increase the chlorophyll content which led to increase photosynthesis and its products.

Table 6. Filled grains $\%$ and 1000-grain weight of Egyptian Hybrid Rice 1 as affected by potassium and Cytokinin treatments during 2014 - 2015 seasons.

\begin{tabular}{|c|c|c|c|c|}
\hline \multirow[t]{2}{*}{ Treatments } & \multicolumn{2}{|c|}{$\begin{array}{c}\text { Filled grain } \\
\%\end{array}$} & \multicolumn{2}{|c|}{$\begin{array}{l}1000 \text { grain } \\
\text { weight g }\end{array}$} \\
\hline & 2014 & 2015 & 2014 & 2015 \\
\hline \multicolumn{3}{|l|}{ Potassium treatments } & 22.66 & 22.71 \\
\hline$\left(\mathrm{K}_{2}\right)$ Basle all amount & 90.12 & 89.91 & 25.77 & 24.88 \\
\hline$\left(\mathrm{K}_{3}\right)^{1 / 2 \mathrm{~B}}+$ SprayMd.T+L.B & 90.03 & 91.86 & 24.99 & 24.81 \\
\hline$\left(\mathrm{K}_{4}\right)^{1 / 2} \mathrm{~B}+$ Spry at Md T & 87.59 & 87.35 & 23.42 & 24.59 \\
\hline$\left(\mathrm{K}_{5}\right)^{1 / 2} \mathrm{~B}+$ Spray at L.B & 88.29 & 87.16 & 24.07 & 24.14 \\
\hline$\left(\mathrm{K}_{6}\right)$ Spray Md.T+ L.B & 87.47 & 87.93 & 23.73 & 23.62 \\
\hline LSD 0.05 & 1.17 & 1.59 & 1.30 & 1.22 \\
\hline \multicolumn{5}{|l|}{ Cytokinin ppm: } \\
\hline$\left(\mathrm{C}_{1}\right)$ Control $(\mathrm{w}$ & 82.16 & & 23.51 & 23.38 \\
\hline$\left(\mathrm{C}_{2}\right) 5 \mathrm{ppm}$ & 85.77 & 86.47 & 23.86 & 23.90 \\
\hline$\left(\mathrm{C}_{3}\right) 10 \mathrm{ppm}$ & 91.17 & 90.25 & 24.57 & 24.63 \\
\hline$\left(\mathrm{C}_{4}\right) 15 \mathrm{ppm}$ & 90.31 & 89.76 & 24.44 & 24.51 \\
\hline LSD & 0.89 & 1.08 & 0.64 & 0.54 \\
\hline Interaction & $* *$ & $* *$ & NS & NS \\
\hline
\end{tabular}


Also, Cytokinin content reach to the high levels in spikelet's and flag leaf at the end of heading that cause an increase in the viability or by the other meaning late in senesces of flag leaf and increase the grain size which receive the great amount of the assimilate stream from the form the photosynthetic products of flag leaf plus second and third leaves which representative about $75 \%$ from the total photosynthesis specially in hybrid rice to fill the greatest number of grains in the big panicles of hybrid rice. Similar trend was found by Silverman et.al (1998).

Data in Table 7 implied that highly significant differences in the interaction between potassium and
Cytokinin application of filled grains percentage in both studied seasons. The Maximum filled grains percentage was obtained when the tested cultivar treated with both of $\mathrm{K}_{2}$ or $\mathrm{K}_{3}$ in combined with both $\mathrm{C}_{3}$ and $\mathrm{C}_{4}$ in both studied seasons. This might be due to the increase in the efficiency of potassium fertilizers applied with Cytokinin and thus led to more uptake of nutrients and photosynthesis products which accumulate more assimilates in grain. Zain and Ismail 2016 reported that increasing potassium fertilizer application reduce percentage of empty spikelet of rice.

Table 7. Filled grain \% of Egyptian Hybrid Rice 1 as affected by the interaction between potassium treatment and Cytokinin concentration during 2014 - 2015 seasons.

\begin{tabular}{|c|c|c|c|c|c|c|c|c|}
\hline \multirow{3}{*}{ Potassium treatments } & \multicolumn{8}{|c|}{ Cytokinin ppm } \\
\hline & \multicolumn{4}{|c|}{2014} & \multicolumn{4}{|c|}{2015} \\
\hline & $\left(C_{1}\right) 0$ & $\left(C_{1}\right) 5$ & $\left(C_{1}\right) 10$ & $\left(C_{1}\right) 15$ & $\left(\mathrm{C}_{1}\right) \mathbf{0}$ & $\left(C_{1}\right) 5$ & $\left(C_{1}\right) \mathbf{1 0}$ & $\left(C_{1}\right) 15$ \\
\hline$\left(\mathrm{K}_{1}\right)$ Control & 80.01 & 80.37 & 80.68 & 81.46 & 80.26 & 80.81 & 81.17 & 81.10 \\
\hline$\left(\mathrm{K}_{2}\right)$ Basle all amount & 83.20 & 88.08 & 95.00 & 94.20 & 84.12 & 88.28 & 93.77 & 93.45 \\
\hline$\left(\mathrm{K}_{3}\right) 1 / 2 \mathrm{~B}+$ Spray Md.T+ L.B & 83.39 & 87.30 & 95.33 & 94.11 & 87.37 & 91.21 & 94.58 & 94.29 \\
\hline$\left(\mathrm{K}_{4}\right)^{1 / 2} \mathrm{~B}+$ Spry at Md T & 81.51 & 86.41 & 91.72 & 90.70 & 82.51 & 86.73 & 90.08 & 90.08 \\
\hline$\left(\mathrm{K}_{5}\right)_{1 / 2} \mathrm{~B}+$ Spray at L.B & 83.33 & 88.33 & 92.31 & 89.20 & 82.40 & 87.00 & 90.30 & 88.95 \\
\hline$\left(\mathrm{K}_{6}\right)$ Spray Md.T+ L.B & 81.53 & 84.14 & 92.00 & 92.20 & 84.67 & 84.79 & 91.58 & 90.67 \\
\hline LSD at 0.05 & \multicolumn{4}{|c|}{2.15} & \multicolumn{4}{|c|}{2.69} \\
\hline
\end{tabular}

Thousand - grain weight as affected by potassium and Cytokinin application are presented in Table 6. Data revealed that all potassium treatments significantly increased 1000 - grain weight as compared with control. The highest value of 1000 - grain was recorded when the tested cultivar was treated with $\mathrm{K} 2$ or K3 in both studied seasons. This could be attributed to that potassium is closely related to the starch synthesis. Since ADP - glucose starch synthesis, which is the primary enzyme for starch synthesis, increase its activity due to the presence of potassium which acts an important physiological function in the quick progress of starch synthesis. These findings are in agreement with those reported by Tanaka et al .1995

Data also indicated that application of Cytokinin significantly increased 1000 - grain weight as compared with control. The highest values of 1000 - grain weight were found when Cytokinin was applied at the concentration of 10 or $15 \mathrm{ppm}$. While the lowest values were obtained when no Cytokinin was applied. These results were holding true for the two seasons the study. The effect of the interaction between potassium and Cytokinin in 1000 - grain weight was not significant in the two seasons of the study.

Grain yield of Egyptian hybrid rice 1 as affected by potassium and Cytokinin treatments are presented in Table 8. Data indicated that grain yield was significantly increased with all potassium application treatments as compared with control in both studied seasons. The highest value of grain yield were recorded when the tested hybrid rice one was treated with $\mathrm{K} 3$ and $\mathrm{K}_{2}$ in both studied seasons. This might be owing to the continuous supply of potassium to the tested hybrid rice one during its different stages which is more beneficial and increased translocation of carbohydrates from stems; leaves and other storage organs to grain, leading to high sink capacity and, subsequently, higher grain yield. Similar trend was obtained by Zaratin et al. 2004 and Pavithira et al. 2017.

Cytokinin application significantly increased the grain yield. as compared with control in the two seasons. Cytokinin at the rate of 10 and 15 ppm significantly increased the grain yield without any significant difference between them as compared with the other treatments in the both studied seasons. Hashem et al. (2016) reported that growth regulators are involved in controlling development events such as cell division, cell elongation and protein synthesis. Plants have the ability to store excessive amounts of exogenously which release active hormone when and where plant needs them during the growth period.

Table 8. Grain and straw yield of Egyptian Hybrid Rice 1 as affected by potassium and Cytokinin treatments during $2014-2015$ seasons.

\begin{tabular}{|c|c|c|c|c|}
\hline \multirow[t]{2}{*}{ Treatments } & \multicolumn{2}{|c|}{$\begin{array}{l}\text { Grain yield } \\
\text { t ha }^{-1}\end{array}$} & \multicolumn{2}{|c|}{$\begin{array}{c}\text { Straw yield } \\
\text { t ha }^{-1}\end{array}$} \\
\hline & 2014 & 2015 & 2014 & 2015 \\
\hline \multicolumn{5}{|l|}{ Potassium treatments } \\
\hline$\left(\mathrm{K}_{1}\right)$ Control & 10.29 & 9.87 & 14.77 & 15.57 \\
\hline$\left(\mathrm{K}_{2}\right)$ Basle all amount & 11.79 & 12.11 & 16.75 & 16.85 \\
\hline$\left(\mathrm{K}_{3}\right)^{1 / 2} \mathrm{~B}+$ SprayMd.T+L.B & 12.11 & 12.21 & 16.88 & 17.56 \\
\hline$\left(\mathrm{K}_{4}\right) 1 / 2 \mathrm{~B}+$ Spry at Md T & 11.20 & 11.25 & 16.83 & 16.72 \\
\hline$\left(\mathrm{K}_{5}\right)^{1 / 2} \mathrm{~B}+\mathrm{S}$ & 11.25 & 11.01 & 16.29 & 15.68 \\
\hline ray Md.T+ L.B & 10.38 & 10.43 & 16.19 & 16.13 \\
\hline LSD 0.05 & 0.31 & 0.23 & 0.65 & 0.48 \\
\hline \multicolumn{5}{|l|}{ Cytokinin ppm: } \\
\hline$\left(\mathrm{C}_{1}\right)$ Control (water spry) & 10.54 & 10.61 & 14.63 & 14.66 \\
\hline$\left(\mathrm{C}_{2}\right) 5 \mathrm{ppm}$ & 11.11 & 11.10 & 16.23 & 16.37 \\
\hline$\left(\mathrm{C}_{3}\right) 10 \mathrm{ppm}$ & 11.57 & 11.49 & 16.70 & 17.06 \\
\hline$\left(\mathrm{C}_{4}\right) 15 \mathrm{ppm}$ & 11.46 & 11.38 & 16.98 & 16.91 \\
\hline LSD at 0.05 & 0.16 & 0.15 & 0.38 & 0.36 \\
\hline Interaction & $* *$ & $* *$ & NS & $\mathrm{NS}$ \\
\hline
\end{tabular}


There was a significant effect on grain yield due to the interaction between potassium and Cytokinin in the two seasons as shown in Table 9. Among the treatments combinations of $\mathrm{K} 3$ with $\mathrm{C} 3$ or $\mathrm{c} 4$ gave the highest grain yield while the lowest grain yield was obtained from the combination of $\mathrm{K} 1$ with $\mathrm{C} 1$. This might be owing to continuous supplying the tested cultivar by potassium through the different stage of its life cycle or duration. The application of potassium basally before planting and at mid tillering enhance the nods to emerge great number of tillers most of them always are effective tillers or number of panicles (Sink capacity). This character's representative about 40 to $60 \%$ of the yield components. The role of potassium also, is controlling the opening and closing stomata that supply the plant by $\mathrm{Co}_{2}$ which is necessary for the first step of photosynthesis. Also, potassium is important for increase the uptake of nitrogen and phosphorus that increase the growth of both roots and shoots beside the increasing in chlorophyll content and the other physiological and biochemical process in the plant. The application of potassium at late booting increases the flag leaf area and the size of grains. Potassium is coactivator for about 64 enzymes in rice plant some of them are transferring enzymes which increase the translocation of carbohydrates, amino acids and oils (assimilates) from the leaves specially flag leaf to fill high number of spikelet's. The activity of these enzymes due to the adequate concentration of potassium cause an increase in filling rate and percentage consequently increase in number of filled grains resulted in increase the grain yield. The hybrid rice always produces tall panicle with high number of spikelet's, so the application of potassium at late booting is necessary for filling most of these spikelet's and minimize the empty grains.

The increase in grain yield due to the application of Cytokinin could be attributed to the role of Cytokinin for increase the viability of leaves as a result to assimilation of protein and increase the chlorophyll content which led to increase photosynthesis and its products. Also, Cytokinin content reach to the high levels in spikelet's and flag leaf at the end of heading that cause an increase in the viability or by the meaning late in senesces of flag leaf and increase the grain size which receive the great amount of the assimilate stream form the photosynthesis of flag leaf plus second and third leaves which representative about $75 \%$ from the total photosynthetic specially in hybrid rice to fill the greatest number of grains in the big panicles of hybrid rice. A similar trend was found by Silverman et.al (1998).

Table 9. Grain yield of Egyptian Hybrid Rice 1 as affected by the interaction between potassium treatment and Cytokinin concentration during $2014-2015$ seasons.

\begin{tabular}{|c|c|c|c|c|c|c|c|c|}
\hline \multirow{3}{*}{ Potassium treatments } & \multicolumn{8}{|c|}{ Cytokinin ppm } \\
\hline & \multicolumn{4}{|c|}{2014} & \multicolumn{4}{|c|}{2015} \\
\hline & $\left(C_{1}\right) 0$ & $\left(C_{1}\right) 5$ & $\left(C_{1}\right) 10$ & $\left(C_{1}\right) 15$ & $\left(C_{1}\right) 0$ & $\left(C_{1}\right) 5$ & $\left(C_{1}\right) 10$ & $\left(C_{1}\right) 15$ \\
\hline$\left(\mathrm{K}_{1}\right)$ Control & 10.14 & 10.23 & 10.39 & 10.38 & 9.70 & 9.82 & 9.90 & 10.07 \\
\hline$\left(\mathrm{K}_{2}\right)$ Basle all amount & 10.99 & 11.76 & 12.49 & 11.93 & 11.42 & 12.23 & 12.42 & 12.35 \\
\hline$\left(\mathrm{K}_{3}\right)^{1 / 2} \mathrm{~B}+$ Spray Md.T+ L.B & 11.28 & 11.92 & 12.85 & 12.40 & 11.63 & 12.44 & 12.66 & 12.12 \\
\hline$\left(\mathrm{K}_{4}\right)^{1 / 2} \mathrm{~B}+$ Spry at Md T & 10.47 & 11.28 & 11.43 & 11.62 & 10.47 & 11.13 & 11.83 & 11.57 \\
\hline$\left(\mathrm{K}_{5}\right)^{1 / 2} \mathrm{~B}+$ Spray at L.B & 10.71 & 11.18 & 11.50 & 11.61 & 10.43 & 10.65 & 11.29 & 11.67 \\
\hline$\left(\mathrm{K}_{6}\right)$ Spray Md.T+ L.B & 9.64 & 10.27 & 10.77 & 10.82 & 10.01 & 10.34 & 10.85 & 10.51 \\
\hline LSD at 0.05 & \multicolumn{4}{|c|}{0.40} & \multicolumn{4}{|c|}{0.30} \\
\hline
\end{tabular}

Straw yield of Egyptian hybrid rice one as influenced by potassium and Cytokinin treatments is presented in table (8).

Data demonstrated that the application of K2, K3 and $\mathrm{K} 4$ in 2014 seasons produced the greatest straw yield, without any significant differences among them while in 2015 season only $\mathrm{K} 3$ treatment produced the highest value in this aspect. On contrasted the lowest value in straw yield was observed in control treatments (K1) in the two studied seasons.

It can be easily observed that all the treatments which received potassium caused an increase in straw yield as compared with control treatments.

Data in the same table increasing Cytokinin concentration from o (C1) to $15 \mathrm{ppm}(\mathrm{C} 4)$ increased straw yield in the two seasons of the study compared to the control.

Hulling percentage in grains of Egyptian hybrid rice one as affected by the application of potassium and Cytokinin in the two studied seasons is presented in Table 10. Data indicated that all potassium treatments caused an increased in hulling \% as compared with control in both studied seasons. The maximum hulling

percentage was obtained when the tested cultivar treated with both $\mathrm{K} 2$ and $\mathrm{K} 3$ in both studied seasons. While the lowest values were obtained with control (K1). This could be attributed to role of potassium for increasing grain filling rate and percentage consequently decreased the hull thickness and weight. There were apparent differences in hulling percentage due to Cytokinin application. There was a significant increase in hulling percentage with increasing Cytokinin concentration as compared with control. The greatest hulling percentage was found with both 10 and $15 \mathrm{ppm}$ in both seasons of study.

Data in Table 11 present the interaction effect of potassium and Cytokinin treatments on hulling percentage. The combination of Cytokinin at the rate of 10 and $15 \mathrm{ppm}$ with $\mathrm{K} 2$ and $\mathrm{K} 3$ recorded the highest percentage of hulling percentage. On the other hand, the lowest values of hulling percentage were detected when plants received neither potassium nor Cytokinin.

Data in Table 10 revealed that all the potassium treatments caused an increase in milling \% as compared with control. The highest value of milling percentage was obtained when the tested cultivar with both $\mathrm{K} 2$ and 
$\mathrm{K} 3$ in the two studied seasons. While the lowest value was obtained with control (K1). The increase in milling percentage by potassium application might be attributed to more $\mathrm{K}$ utilized by the hybrid rice under study resulted in more efficient translocation of assimilates from source to sink. Application of Cytokinin significantly increased milling percentage. The highest value was recorded when the tested rice cultivar was sprayed with 10 or 15 ppm Cytokinin at mid-tillering and late booting period.

The effect of the interaction between potassium and Cytokinin treatments on milling percentage in the two seasons of study is presented in Table 12. The highest milling rice percentage was obtained from the combination of 10 or 15 ppm Cytokinin at mid-tillering and late booting period with $\mathrm{K} 2$ or $\mathrm{K} 3$ potassium treatments.

The effects of potassium and Cytokinin application on head rice $\%$ in the two seasons are presented in Table 10 . Data showed that head rice $\%$ of rice grain significantly increased with the application of all potassium treatments as compared with control. The highest values of head rice $\%$ were realized when plants treated with $\mathrm{K} 2$ or K3. While the lowest values of head rice \% were obtained when potassium was not applied. Data also indicated that application of Cytokinin significantly increased head rice

$\%$ of rice grains as compared with control in both seasons. Application of 10 or $15 \mathrm{ppm}$ Cytokinin produced the greatest head rice $\%$ compared with 0 and $5 \mathrm{ppm}$ Cytokinin.

Table 10. Hulling, Milling and Head Rice \% of Egyptian Hybrid Rice 1 as affected by potassium and Cytokinin treatments during 2014 - 2015 seasons.

\begin{tabular}{|c|c|c|c|c|c|c|}
\hline \multirow[t]{2}{*}{ Treatments } & \multicolumn{2}{|c|}{$\begin{array}{c}\text { Hulling } \\
\%\end{array}$} & \multicolumn{2}{|c|}{$\begin{array}{c}\text { Milling } \\
\%\end{array}$} & \multicolumn{2}{|c|}{$\begin{array}{c}\text { Head Rice } \\
\% \\
\end{array}$} \\
\hline & 2014 & 2015 & 2014 & 2015 & 2014 & 2015 \\
\hline \multicolumn{7}{|l|}{ Potassium treatments } \\
\hline & 71.11 & 72.11 & 62.06 & 62.77 & 49.0 & 50.23 \\
\hline & & & & & & 6.62 \\
\hline & & & & 69.42 & & 5.98 \\
\hline & & & & 6 & & 2.78 \\
\hline & & & & & & 4.5 \\
\hline 3 & 74.07 & 74.29 & 64.45 & 65.62 & & 50.58 \\
\hline LSD 0.05 & 0.60 & 0.44 & 1.22 & 1.21 & 1.08 & 1.11 \\
\hline \multicolumn{7}{|l|}{ Cytokinin ppm: } \\
\hline & & & & & & \\
\hline 2) & 75. & 76. & 65 & 66. & 52 & 53.1 \\
\hline C.3 1 & 75. & 76.69 & 66.8 & 67.57 & 54. & 54.97 \\
\hline $\left.\mathrm{C}_{4}\right)$ & 75.65 & 76.63 & 66.50 & 67.52 & 53.62 & 54.24 \\
\hline $\mathrm{SD}$ a & 0.40 & 0.23 & 0.50 & 1.03 & 0.69 & 0.70 \\
\hline teraction & . & . & & 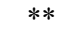 & $*$ & \\
\hline
\end{tabular}

Table 11. Hulling \% of Egyptian Hybrid Rice 1 as affected by the interaction between potassium treatment and Cytokinin concentration during 2014 - 2015 seasons.

\begin{tabular}{|c|c|c|c|c|c|c|c|c|}
\hline \multirow{3}{*}{ Potassium treatments } & \multicolumn{8}{|c|}{ Cytokinin ppm } \\
\hline & \multicolumn{4}{|c|}{2014} & \multicolumn{4}{|c|}{2015} \\
\hline & $\left(C_{1}\right) 0$ & $\left(C_{1}\right) 5$ & $\left(C_{1}\right) 10$ & $\left(C_{1}\right) 15$ & $\left(C_{1}\right) 0$ & $\left(C_{1}\right) 5$ & $\left(C_{1}\right) 10$ & $\left(C_{1}\right) 15$ \\
\hline$\left(\mathrm{K}_{1}\right)$ Control & 69.55 & 70.97 & 71.82 & 72.11 & 71.23 & 72.11 & 72.71 & 72.38 \\
\hline$\left(\mathrm{K}_{2}\right)$ Basle all amount & 75.11 & 76.42 & 77.67 & 76.89 & 76.11 & 77.33 & 79.71 & 79.33 \\
\hline$\left(\mathrm{K}_{3}\right)^{1 / 2} \mathrm{~B}+$ Spray Md.T+ L.B & 74.67 & 76.64 & 76.68 & 76.93 & 75.31 & 78.23 & 79.03 & 78.53 \\
\hline$\left(\mathrm{K}_{4}\right) 1 / 2 \mathrm{~B}+$ Spry at Md T & 73.88 & 76.18 & 76.78 & 76.39 & 75.2 & 76.22 & 77.93 & 77.44 \\
\hline$\left(\mathrm{K}_{5}\right) 1 / 2 \mathrm{~B}+$ Spray at L.B & 74.22 & 76.31 & 76.16 & 76.67 & 75.53 & 78.11 & 75.83 & 77.22 \\
\hline$\left(\mathrm{K}_{6}\right)$ Spray Md.T+ L.B & 73.00 & 73.71 & 74.67 & 74.89 & 73.11 & 74.22 & 74.93 & 74.88 \\
\hline LSD at 0.05 & \multicolumn{4}{|c|}{0.88} & \multicolumn{4}{|c|}{1.06} \\
\hline
\end{tabular}

Table 12. Milling \% of Egyptian Hybrid Rice 1 as affected by the interaction between potassium treatment and Cytokinin concentration during 2014 - 2015 seasons.

\begin{tabular}{|c|c|c|c|c|c|c|c|c|}
\hline \multirow{3}{*}{ Potassium treatments } & \multicolumn{8}{|c|}{ Cytokinin ppm } \\
\hline & \multicolumn{4}{|c|}{2014} & \multicolumn{4}{|c|}{2015} \\
\hline & $\left(C_{1}\right) 0$ & $\left(C_{1}\right) 5$ & $\left(C_{1}\right) 10$ & $\left(C_{1}\right) 15$ & $\left(C_{1}\right) 0$ & $\left(C_{1}\right) 5$ & $\left(C_{1}\right) 10$ & $\left(C_{1}\right) 15$ \\
\hline$\overline{\left(\mathrm{K}_{1}\right) \text { Control }}$ & 60.22 & 61.78 & 63.11 & 63.11 & 61.17 & 62.67 & 63.46 & 63.77 \\
\hline$\left(\mathrm{K}_{2}\right)$ Basle all amount & 65.56 & 69.78 & 69.67 & 69.67 & 67.22 & 70.90 & 70.12 & 70.23 \\
\hline$\left(\mathrm{K}_{3}\right)^{1 / 2} \mathrm{~B}+$ Spray Md.T+ L.B & 65.00 & 67.89 & 70.22 & 70.22 & 66.34 & 70.16 & 70.70 & 70.49 \\
\hline$\left(\mathrm{K}_{4}\right)^{1 / 2} \mathrm{~B}+$ Spry at Md T & 63.08 & 64.89 & 65.78 & 65.78 & 63.28 & 64.32 & 65.67 & 65.69 \\
\hline$\left(\mathrm{K}_{5}\right) 1 / 2 \mathrm{~B}+$ Spray at L.B & 63.11 & 64.44 & 66.22 & 66.22 & 65.90 & 66.55 & 67.66 & 67.12 \\
\hline$\left(\mathrm{K}_{6}\right)$ Spray Md.T+ L.B & 62.44 & 63.45 & 65.89 & 65.89 & 63.20 & 63.67 & 67.80 & 67.82 \\
\hline LSD at 0.05 & \multicolumn{4}{|c|}{1.55} & \multicolumn{4}{|c|}{1.52} \\
\hline
\end{tabular}

Regarding the effect of potassium and Cytokinin interaction on head rice percentage, data in Table 13 showed that high value of head rice $\%$ was found when $\mathrm{K} 2$ or $\mathrm{K} 3$ potassium treatments were combined with either 10 or 15 ppm Cytokinin. On the other hand, the lowest head rice \% was found with the treatment, which did not receive any Cytokinin treatments (control).

Nitrogen, phosphorus and potassium uptake in rice grains of Egyptian hybrid rice 1 as influenced by potassium application and Cytokinin treatments are presented in Table 14

Data clarified that all the potassium treatments caused an increase in the uptake of $\mathrm{N}, \mathrm{P}$ and $\mathrm{K}$ as compared with control. The greatest values of the uptake of the previous their nutrients were observed when the tested cultivar treated by K3 treatment, while the lowest values were found in control treatment. The increase in the uptake of $\mathrm{N}, \mathrm{P}$ and $\mathrm{K}$ nutrients under $\mathrm{K} 3$ treatment could be attributed to the continuous supply 
the tested cultivar by $\mathrm{K}$ at different stages. The application of $\mathrm{K}$ as half of the total dose basally improves the root growth (depth and distribution) beside the increase in vascular system or bundle specially xylem which translocate the nutrients from roots to shoots. Moreover, sprayed the rice cultivar under study at $\mathrm{Md}$. T., increase the number of tillers and leaves (canopy of plant) that increase the photosynthesis and other biochemical processes resulted in increase the metabolic absorption of the nutrients from the soil solution consequently increase the concentration of the nutrients in the leaves.

Also, sprayed the tested cultivar by $\mathrm{K}$ at late booting is necessary for translocated the assimilates and nutrients from the leaves to the spikelet's because of the role of $\mathrm{K}$ for translocation of assimilate and nutrients form source to sink of plant due to function for activating the transferring enzymes. It could be concluded that the application of $\mathrm{K}$ basally plus sprayed at both mid-tillering and late booting improved root system and power that increase the absorption of nutrients physically throw xylem as a result to negative power (transpiration) or as metabolic absorption which need energy and cause an increase in the concentration of their nutrients in the leaves which translocated and accumulated in grains consequently increase its \% in grains. These findings are in close conformity with Dwived et al. (2006).

As for Cytokinin application data in the same table indicated that sprayed the tested cultivar by the three studied levels significantly increases the uptake of the three nutrients under study as compared with control (without Cytokinin).

The highest uptake of nitrogen, phosphorus and potassium was found when the tested cultivar sprayed by $15 \mathrm{ppm}$ Cytokinin. It might be due to the role of Cytokinin for improving the growth of roots by increasing cell division and elongation. Also, because of Cytokinin synthesized in the roots and assimilate the nitrogen and produced amino acids that increase the viability of roots consequently increases the activity of absorption of nutrients.

Table 13. Head Rice \% of Egyptian Hybrid Rice 1 as affected by the interaction between potassium treatment and Cytokinin concentration during 2014 - 2015 seasons.

\begin{tabular}{|c|c|c|c|c|c|c|c|c|}
\hline \multirow{3}{*}{ Potassium treatments } & \multicolumn{8}{|c|}{ Cytokinin ppm } \\
\hline & \multicolumn{4}{|c|}{2014} & \multicolumn{4}{|c|}{2015} \\
\hline & $\left(C_{1}\right) 0$ & $\left(C_{1}\right) 5$ & $\left(C_{1}\right) 10$ & $\left(C_{1}\right) 15$ & $\left(C_{1}\right) 0$ & $\left(C_{1}\right) 5$ & $\left(C_{1}\right) \mathbf{1 0}$ & $\left(C_{1}\right) 15$ \\
\hline$\left(\mathrm{K}_{1}\right)$ Control & 47.78 & 49.22 & 49.55 & 49.78 & 49.11 & 50.13 & 50.75 & 50.94 \\
\hline$\left(\mathrm{K}_{2}\right)$ Basle all amount & 52.34 & 54.33 & 56.72 & 56.78 & 53.08 & 55.46 & 59.45 & 58.47 \\
\hline$\left(\mathrm{K}_{3}\right)^{1 / 2} \mathrm{~B}+$ Spray Md.T+ L.B & 52.06 & 55.06 & 58.11 & 57.28 & 52.12 & 56.23 & 58.33 & 57.24 \\
\hline$\left(\mathrm{K}_{4}\right) 1 / 2 \mathrm{~B}+$ Spry at Md T & 50.87 & 53.11 & 54.67 & 53.55 & 50.78 & 52.67 & 54.23 & 53.45 \\
\hline$\left(\mathrm{K}_{5}\right) 1 / 2 \mathrm{~B}+$ Spray at L.B & 51.22 & 52.55 & 55.33 & 53.33 & 53.77 & 54.33 & 55.90 & 54.00 \\
\hline$\left(\mathrm{K}_{6}\right)$ Spray Md.T+ L.B & 49.55 & 50.29 & 51.28 & 51.00 & 49.77 & 50.04 & 51.18 & 51.33 \\
\hline LSD at 0.05 & \multicolumn{4}{|c|}{1.76} & \multicolumn{4}{|c|}{1.79} \\
\hline
\end{tabular}

Table 14. Nitrogen, phosphorus and potassium uptake by rice grain of Egyptian Hybrid Rice 1 as affected by potassium and Cytokinin treatments during 2014 - 2015 seasons.

\begin{tabular}{|c|c|c|c|c|c|c|}
\hline \multirow{2}{*}{ Treatments } & \multicolumn{2}{|c|}{ N uptake } & \multicolumn{2}{|c|}{ P uptake } & \multicolumn{2}{|c|}{ K uptake } \\
\hline & 2014 & 2015 & 2014 & 2015 & 2014 & 2015 \\
\hline \multicolumn{7}{|l|}{ Potassium treatments } \\
\hline$\left(\mathrm{K}_{1}\right)$ Control & 12.27 & 12.76 & 1.744 & 1.922 & 5.269 & 5.340 \\
\hline$\left(\mathrm{K}_{2}\right)$ Basle all amount & 17.44 & 17.66 & 2.782 & 3.021 & 7.458 & 7.755 \\
\hline$\left(\mathrm{K}_{3}\right) 1 / 2 \mathrm{~B}+$ Spray Md.+ L.B & 18.48 & 18.09 & 2.969 & 3.089 & 7.871 & 7.964 \\
\hline$\left(\mathrm{K}_{4}\right) 1 / 2 \mathrm{~B}+$ Spry at Md T & 15.86 & 16.62 & 2.553 & 2.526 & 7.186 & 6.944 \\
\hline$\left(\mathrm{K}_{5}\right) 1 / 2 \mathrm{~B}+$ Spray at L.B & 15.35 & 15.95 & 2.432 & 2.255 & 7.112 & 6.873 \\
\hline$\left(\mathrm{K}_{6}\right)$ Spray Md.T + L.B & 15.14 & 14.81 & 2.168 & 2.300 & 6.683 & 6.379 \\
\hline LSD 0.05 & 0.422 & 0.56 & 0.12 & 0.060 & 0.1923 & 0.1387 \\
\hline \multicolumn{7}{|l|}{ Cytokinin ppm: } \\
\hline$\left(\mathrm{C}_{1}\right)$ Control (water spry) & 13.11 & 13.98 & 2.037 & 2.085 & 6.036 & 6.300 \\
\hline$\left(\mathrm{C}_{2}\right) 5 \mathrm{ppm}$ & 15.08 & 15.68 & 2.386 & 2.364 & 6.932 & 6.710 \\
\hline$\left(\mathrm{C}_{3}\right) 10 \mathrm{ppm}$ & 16.77 & 16.77 & 2.814 & 2.804 & 7.322 & 7.275 \\
\hline$\left(\mathrm{C}_{4}\right) 15 \mathrm{ppm}$ & 17.40 & 17.63 & 2.995 & 2.822 & 7.489 & 7.318 \\
\hline LSD at 0.05 & 0.23 & 0.393 & 0.10 & 0.043 & 0.112 & 0.095 \\
\hline Interaction & $*$ & $*$ & $*$ & $* *$ & $*$ & $*$ \\
\hline
\end{tabular}

The interaction between potassium treatments and Cytokinin levels on nitrogen, phosphorus and potassium uptake are presented in tables 15,16 and 17.

Data revealed that there was a significant difference among all the treatments in the uptake of the three nutrients under study.

The greatest uptake of $\mathrm{N}, \mathrm{P}$ and $\mathrm{K}$ was observed when $\mathrm{K} 3$ treatment was combined with $\mathrm{C} 4$ treatment
(15 ppm Cytokinin). It might be due to increase the role and function of potassium due to the application of Cytokinin that synthesized in rice roots consequently improve the growth of roots by increase the number of cell division and elongation.

Also, the Cytokinin either free or bound in roots controls the process of nitrogen assimilation in the free amino acids which increase the viability of roots and its 
power. The free amino acids translocate with Cytokinin from roots to shoots and used as a materials for protein synthesis in the shoots. Because of the enzymes are protein in nature and $\mathrm{K}$ is co-activator for enzymes, so the $\mathrm{K}$ easily used the required molecules of protein to form about 60 to 64 enzymes in rice plant.

Also, Cytokinin increases the leaf area and a viability of these leaves as a result to increase in protein and chlorophyll. In this case the role and function of potassium will be increased due to the increase in the activity of enzymes which has potassium as co-factor. These enzymes are necessary for the physiological and biological process in plant such as the active absorption of nutrient, photosynthesis, dry matter production and the active translocation of assimilate from source to sink also, Cytokinin is present in the panicle during flowering and increase the size of grains which greatly fill by the carbohydrate (starchy endosperm), lipids, protein and nutrients.

Table 15. Nitrogen uptake by rice grain of Egyptian Hybrid Rice 1 as affected by the interaction between potassium treatment and Cytokinin concentration during 2014 - 2015 seasons.

\begin{tabular}{|c|c|c|c|c|c|c|c|c|}
\hline \multirow{3}{*}{ Potassium treatments } & \multicolumn{8}{|c|}{ Cytokinin ppm } \\
\hline & \multicolumn{4}{|c|}{2014} & \multicolumn{4}{|c|}{2015} \\
\hline & $\left(C_{1}\right) 0$ & $\left(C_{1}\right) 5$ & $\left(C_{1}\right) 10$ & $\left(C_{1}\right) 15$ & $\left(C_{1}\right) 0$ & $\left(C_{1}\right) 5$ & $\left(C_{1}\right) 10$ & $\left(C_{1}\right) 15$ \\
\hline$\left(\mathrm{K}_{1}\right)$ Control & 11.72 & 12.10 & 12.50 & 12.76 & 12.05 & 12.42 & 12.75 & 13.82 \\
\hline$\left(\mathrm{K}_{2}\right)$ Basle all amount & 14.43 & 18.35 & 18.64 & 18.34 & 16.00 & 19.57 & 17.16 & 19.10 \\
\hline$\left(\mathrm{K}_{3}\right)^{1 / 2} \mathrm{~B}+$ Spray Md.T+ L.B & 14.71 & 15.85 & 19.27 & 20.08 & 15.00 & 17.33 & 20.12 & 20.52 \\
\hline$\left(\mathrm{K}_{4}\right)^{1 / 2} \mathrm{~B}+$ Spry at Md T & 13.19 & 14.85 & 17.03 & 18.36 & 14.45 & 15.47 & 17.78 & 18.79 \\
\hline$\left(\mathrm{K}_{5}\right) \frac{1}{2} \mathrm{~B}+$ Spray at L.B & 12.85 & 14.53 & 16.56 & 17.45 & 13.49 & 14.77 & 16.90 & 18.63 \\
\hline$\left(\mathrm{K}_{6}\right)$ Spray Md.T+ L.B & 11.76 & 14.78 & 16.58 & 17.42 & 12.91 & 14.48 & 15.90 & 15.94 \\
\hline LSD at 0.05 & \multicolumn{4}{|c|}{0.62} & \multicolumn{4}{|c|}{0.97} \\
\hline
\end{tabular}

Table 16. Phosphorus uptake by rice grain of Egyptian Hybrid Rice 1 as affected by the interaction between potassium treatment and Cytokinin concentration during $2014-2015$ seasons.

\begin{tabular}{|c|c|c|c|c|c|c|c|c|}
\hline \multirow{3}{*}{ Potassium treatments } & \multicolumn{8}{|c|}{ Cytokinin ppm } \\
\hline & \multicolumn{4}{|c|}{2014} & \multicolumn{4}{|c|}{2015} \\
\hline & $\left(C_{1}\right) 0$ & $\left(C_{1}\right) 5$ & $\left(C_{1}\right) 10$ & $\left(C_{1}\right) 15$ & $\left(C_{1}\right) 0$ & $\left(C_{1}\right) 5$ & $\left(C_{1}\right) \mathbf{1 0}$ & $\left(C_{1}\right) 15$ \\
\hline$\left(\mathrm{K}_{1}\right)$ Control & 1.498 & 1.542 & 2.014 & 1.924 & 1.685 & 1.832 & 2.192 & 1.980 \\
\hline$\left(\mathrm{K}_{2}\right)$ Basle all amount & 2.272 & 3.098 & 3.255 & 2.904 & 2.590 & 3.166 & 3.445 & 2.881 \\
\hline$\left(\mathrm{K}_{3}\right)^{1 / 2} \mathrm{~B}+$ Spray Md.T+ L.B & 2.408 & 2.781 & 3.298 & 3.888 & 2.464 & 2.733 & 3.332 & 3.828 \\
\hline$\left(\mathrm{K}_{4}\right) 1 / 2 \mathrm{~B}+$ Spry at $\mathrm{Md} \mathrm{T}$ & 2.234 & 2.295 & 3.009 & 2.673 & 1.954 & 2.300 & 2.917 & 2.933 \\
\hline$\left(\mathrm{K}_{5}\right)^{1 / 2} \mathrm{~B}+$ Spray at L.B & 2.106 & 2.308 & 2.761 & 2.553 & 1.948 & 2.017 & 2.409 & 2.644 \\
\hline$\left(\mathrm{K}_{6}\right)$ Spray Md.T+ L.B & 1.702 & 2.293 & 2.548 & 2.128 & 1.868 & 2.137 & 2.531 & 2.663 \\
\hline LSD at 0.05 & \multicolumn{4}{|c|}{0.223} & \multicolumn{4}{|c|}{0.104} \\
\hline
\end{tabular}

Table 17. Potassium uptake by rice grain of Egyptian Hybrid Rice 1 as affected by the interaction between potassium treatment and Cytokinin concentration during $2014-2015$ seasons.

\begin{tabular}{|c|c|c|c|c|c|c|c|c|}
\hline \multirow{3}{*}{ Potassium treatments } & \multicolumn{8}{|c|}{ Cytokinin ppm } \\
\hline & \multicolumn{4}{|c|}{2014} & \multicolumn{4}{|c|}{2015} \\
\hline & $\left(C_{1}\right) 0$ & $\left(C_{1}\right) 5$ & $\left(C_{1}\right) 10$ & $\left(C_{1}\right) 15$ & $\left(C_{1}\right) 0$ & $\left(C_{1}\right) 5$ & $\left(C_{1}\right) 10$ & $\left(C_{1}\right) 15$ \\
\hline$\left(\mathrm{K}_{1}\right)$ Control & 5.271 & 5.411 & 5.066 & 5.328 & 4.690 & 5.124 & 5.608 & 5.938 \\
\hline$\left(\mathrm{K}_{2}\right)$ Basle all amount & 6.153 & 7.646 & 8.156 & 7.876 & 7.007 & 7.625 & 8.113 & 8.275 \\
\hline$\left(\mathrm{K}_{3}\right)^{1 / 2} \mathrm{~B}+$ Spray Md.T+ L.B & 6.393 & 7.468 & 8.823 & 8.860 & 7.210 & 7.879 & 8.604 & 8.861 \\
\hline$\left(\mathrm{K}_{4}\right)^{1 / 2} \mathrm{~B}+$ Spry at Md T & 6.317 & 7.560 & 7.314 & 7.553 & 6.317 & 6.752 & 7.530 & 7.177 \\
\hline$\left(\mathrm{K}_{5}\right) 1 / 2 \mathrm{~B}+$ Spray at L.B & 6.424 & 7.002 & 7.362 & 7.660 & 6.539 & 6.606 & 7.037 & 7.312 \\
\hline$\left(\mathrm{K}_{6}\right)$ Spray Md.T+ L.B & 5.655 & 6.503 & 7.214 & 7.359 & 6.036 & 6.275 & 6.760 & 6.445 \\
\hline LSD at 0.05 & \multicolumn{4}{|c|}{0.293} & \multicolumn{4}{|c|}{0.237} \\
\hline
\end{tabular}

\section{CONCLUSION}

According to the previous resulted. It can be concluded that the half of the recommended dose of potassium was saved with the increase in both grain yield and milling output by about $10 \%$ in Egyptian hybrid ricel due to the improving in filling \%,weight of panicle ,number of panicles and other yield component as a result to the application of only one half of the recommended dos of potassium as basal $+2 \% \quad \mathrm{~K}_{2} \mathrm{O}$ sprayed at both midtillering (15 days after transplanting) and late booting (95days after transplanting ) (K3 ) which cause continuous supply of potassium through the different stages of plant with spraying $15 \mathrm{ppm}$ Cytokinin at both mid-tillering and late booting which increase root growth and viability of rice leaves specially flag leaf during ripening stage as well as the increase in function of potassium that increase the activity of transferring enzymes and starch synthetase.

\section{REFERENCES}

Ali, A.; M.S. Zia ; F.Hussain ; M.Slim and A. Shahzad (2005). Efficacy of different methods of potassium fertilizer application on paddy yield, $\mathrm{K}$ uptake and agronomic efficiency . Pakistan , J . Agric.Sci., 42(1-2):27-32. 
Chapman ,H.D. and P.F.part (1961). "Method of Analysis for soils, plant and water". Univ. of California, USA

Cottenie, A.M. Verloo; L. Kiekens, G. Velghe and R. Camerlynch (1982). Chemical Analysis of Plants and Soils. Laboratory of Analytical Agro. Chemistry state University, Ghent Belgium.

Dwivedi, A.P.;R.SDixit and G.R.singh (2006). Effect of nitrogen, phosphorus and potassium levels on growth, yield and qulity of hybrid rice ( Oryza sativa) . Ind. J. Agron., 43(1):64-66.

Gomez, K.A. and Gomez (1984).Statistical Procedures for Agriculture Research, An International rice Research Institute Book John Willy and Sons . Inc., New york, USA.

Hafez , A.A.R. and D.S. Mikkelson (1981). Colorimetric determination of nitrogen for evaluating the nutrition status of rice. soil Sci . and plant Analy. 12(1):61-69.

Hashem, M.I.; E.S.Naeem; T.F. Metwally and H.M. El sharkawi (2016). Enhancement of lodging resisance and productivity of rice using growth regulators at different nitrogen levels. J. plant breeding and crop Sci., (3):34- 44.

Jackson, M.L.(1967). "Soil Chemical Analysis". Printic Hall of India , New Delhi : 144-197.

Jianchang yang, S. Peng R.M. Visperas, A,L, Sanico, Z . Zhu and S. Gu (2000). Grain filling pattern and Cytokinin content in the grains and roots of rice plants .

Olsen, S.R.; and L.A. Deam (1965) . phosphorus soluble in sodium bicarbonate In C.A. Black (ed) Method of soil Analysis, Part2. Agronomy. 9:1044-1064 .

Pandey, N.,S.K. Upadhyay, R.S.Tripathi (2001) Effect of plant growth regulators and fertility levels on growth and yield of transplanted rice. Ind. J. Agric. Res. 35(3):205-207.
Pavithira, E., Sirisena, D.N. \& Herath, H.M.S.K., (2017). Effect of Potassium Fertilizer Split Applications together with Straw on Optimum Level in Leaf and Stem of Rice. J. Agric. Sci., 12(1):24-2-33.

Sakakibara,H.,K. Takei, N., Hirose (2006) Interaction between nitrogen and Cytokinin in the regulation of metabolism and development . Trends plant Sci., 11:440-448.

Silverman, F.P., A .A.Assiamah and D.S.Bush (1998). Membrane transport and Cytokinin action in root hairs of Medicago sativa. Planta, 205: 23-31.

Snedecor, G. W. and W. G. Cocharan (1980).Statistical Methods 7 Ed. The Iowa state Univ. press,Iowa , USA.

Tanaka, K.;Z. Kasai and M. ogawa, (1995). Physiology of rippin Secience of the rice plants. Volume two, physiology. Food and Agricultural police Research Center, Tokyo. 97-118.

Thakur D.S., S.R. Patel and S. Nageshwarlal (1999). Effect of Spilt application of application of potassium with FYM on rice (Oryza sativa). Ind. J. Agron., 44(2) :301-304.

Watanabe, F.S., and S.A. Olsen (1965). Calorimetric determination of phosphorus in water extrat of soil. Soil Sci., 94:183-188.

Zain, N.A. and M.R. Ismail. (2016). Effects of potassium rates and types on growth, leaf gas exchange and biochemical changes in rice (Oryza sativa) planted under cyclic water stress. Agric. Water Manag.,164:83-90.

Zaratin, C.;S.A. Souza; A.C. Pantano; M.E. Sa and S. Buzetti (2004). Effects of four potassium doses on six sprinkler irrigated rice upland cultivars .I. yield and yield components . Cientica Jaboticabal, 32(2);115-120.

\footnotetext{
تحسين محصول الأرز هجين مصرى واحد وبعض صفات جودة الحبوب و إمتصاص بعض العناصر الغذائية بإضافة السماد البوتاسى وهرمون السيتوكينين

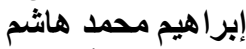
قسم بحوث الأرز - معهد بحوث هائ المحاصيل الحقلية ـ مركز البحوث الزراعية

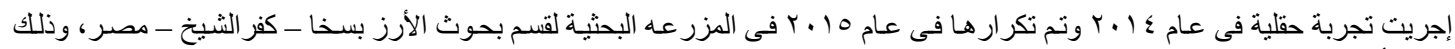

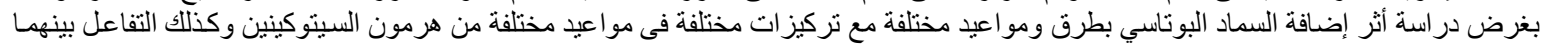

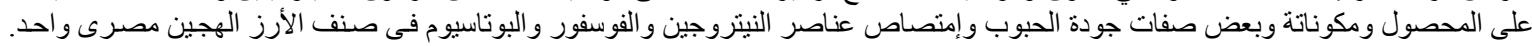

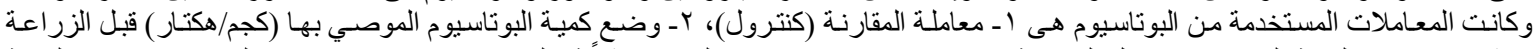

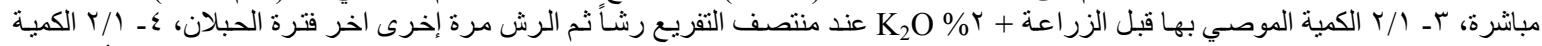

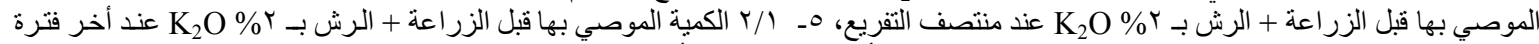

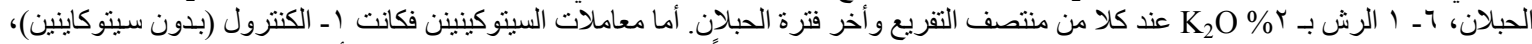

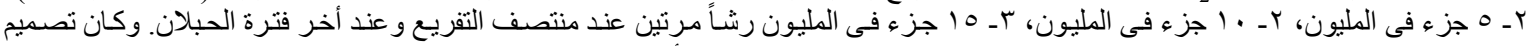

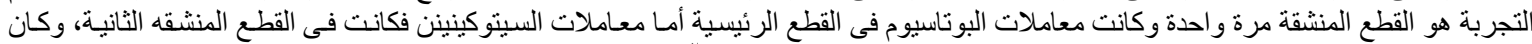

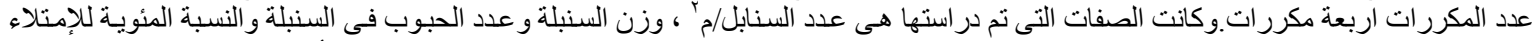

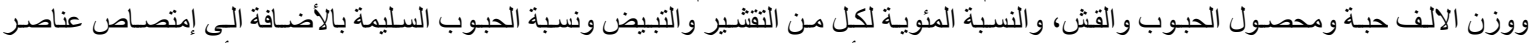

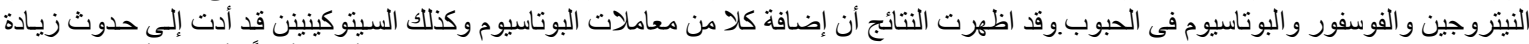

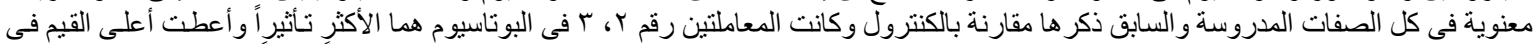

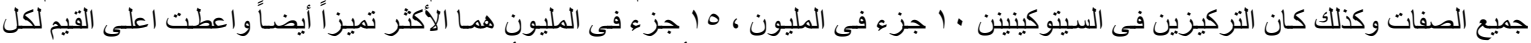

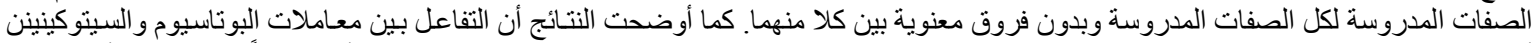

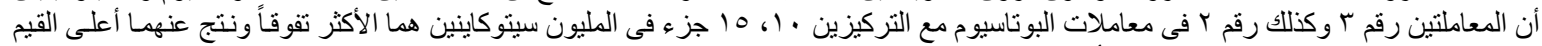

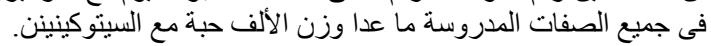

